\title{
DENDROARCHAEOLOGY IN SOUTHWESTERN NOVA SCOTIA AND THE CONSTRUCTION OF A REGIONAL RED SPRUCE CHRONOLOGY
}

\author{
ANDRÉ ROBICHAUD* and COLIN P. LAROQUE \\ Mount Allison Dendrochronology Laboratory, Department of Geography, Mount Allison University, Sackville, New \\ Brunswick E4L 1A7, Canada
}

\begin{abstract}
Dendrochronology studies in Atlantic Canada are rare partly because old-growth forests are scarce making it difficult to establish multiple-century tree-ring chronologies. One approach to overcome this problem is to use tree-ring records found in the wood of historical structures. For our study, the Sinclair Inn in Annapolis Royal, Nova Scotia, was selected for a dendroarchaeological assessment because of its rich and complex history: it resulted from the merging of two early $18^{\text {th }}$ Century houses (the Soullard and Skene houses). To date the Sinclair Inn, three other historical structures of a younger age were used to establish an annual ring record in lieu of old-growth forest data. Red spruce (Picea rubens), a dominant tree species in the Maritimes, was the most prominent wood found in the structures and allowed for the creation of a regional red spruce reference chronology extending far enough into the past to cover the supposed period of construction of the Sinclair Inn. Crossdating results indicate cutting dates of 1709 and 1710 for the Skene and Soullard houses, respectively, and 1769 for the inn itself. In the process of dating the structure, a 200-year long regional floating red spruce chronology (1591-1789) was developed that will further help future dendrochronological investigations in the Maritimes.
\end{abstract}

Keywords: Dendroarchaeology, red spruce, Picea rubens, Nova Scotia, Annapolis Royal.

\section{INTRODUCTION}

Few tree-ring chronologies exist in the Atlantic provinces of Canada (ITRDB 2007). The reason is partly because old-growth forests in the region are particularly scarce, where less than $3 \%$ of the forest is estimated to be older than 100 years (Wilson and Coleman 2001). Because of logging, frequent insect outbreaks, and fires, finding trees in the region suitable to build long chronologies remains difficult (Loo and Ives 2003). For these reasons, little scientific inquiry has focused on dendrochronological research in the region, leaving it largely unexplored.

One solution to compensate for the lack of old living trees is to use timbers from historical buildings to extend chronologies. Although dendroarchaeological methods are fairly well-established (Baillie 1982; Schweingruber 1988; Nash 2002; Wight and Grissino-Mayer 2004), few attempts at tree-ring dating of buildings have ever

\footnotetext{
*Corresponding author: arobicha@mta.ca
}

been conducted in Atlantic Canada. Because Atlantic Canada is one of the oldest colonized regions in North America, it harbors an abundance of old wooden structures that are perfectly suited for such methods.

The Annapolis Royal region is one such area, and it is the focus of this study. It is situated in southwestern Nova Scotia, along the Bay of Fundy (Figure 1). The area was colonized by the French as early as 1605 and was cleared for agriculture throughout the $1600 \mathrm{~s}$ and $1700 \mathrm{~s}$ (Fergusson 1967). Forestry in Nova Scotia has a long history (Johnson 1986) and it is apparent that the Annapolis Valley and surrounding region underwent extensive logging very early. Nova Scotia forest inventories indicate that old-growth forest has become scarce throughout the province, declining from $9 \%$ of the trees being over 100 years old in 1958 (Hawboldt and Bulmer 1958) to only approximately 3\% in 2003 (Townsend 2004). Indeed, genuine old-growth forests are now only found in small isolated pockets, with 


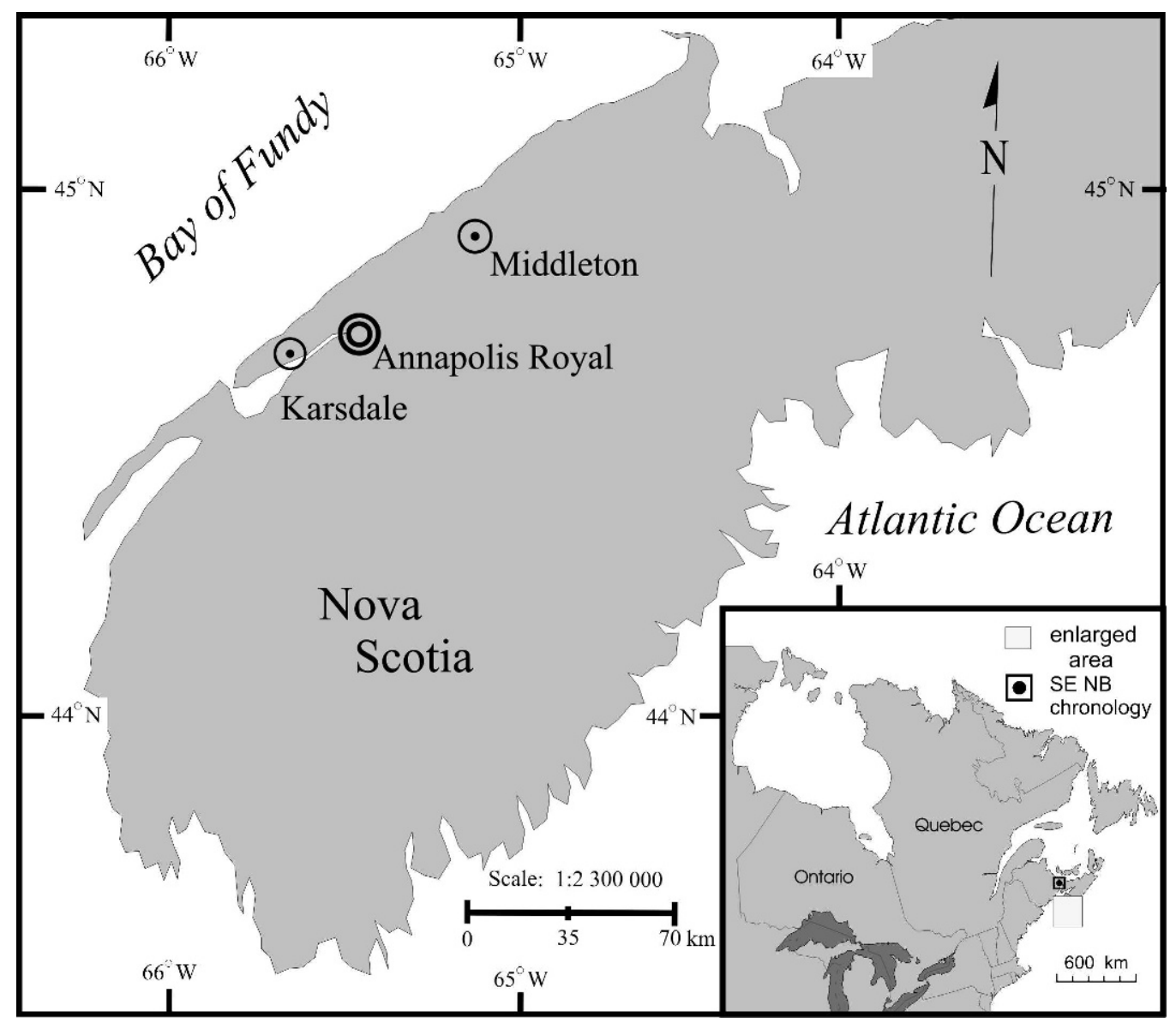

Figure 1. Location of the study site and the Karsdale and Middleton churches in southwestern Nova Scotia.

even these slowly disappearing (Wilson and Colman 2001). This situation presents a challenge in building extensive tree-ring chronologies for the whole area. However, given the fact that its history is fairly well recorded, the possibility exists of developing and extending continuous tree-ring chronologies further back in time using wooden structures.

The aim of this paper is to present some of the first dendroarchaeological research in Atlantic Canada and to illustrate that, even though major difficulties involved in building tree-ring chronologies in the area exist, dendroarchaeological studies will be the key to creating any long-lived chronologies in this under-investigated region. To accomplish this goal, we will use a case study of the Sinclair Inn in Annapolis Royal, Nova Scotia, to illustrate the viable working procedure currently used to develop long chronologies in the region.

\section{The Sinclair Inn}

After an early and difficult settlement attempt at Ste-Croix Island in 1604, Samuel de Champlain founded Port-Royal in 1605. It became the administrative and military center of Acadie, and was later renamed Annapolis Royal by the British when it was captured in 1710. It is considered to be one of the earliest European settlements in North America, and as such, many heritage buildings survive in the town and area.

Among the old structures still standing in Annapolis Royal is the Sinclair Inn (Figure 2). The inn is an old two-story wood frame building 


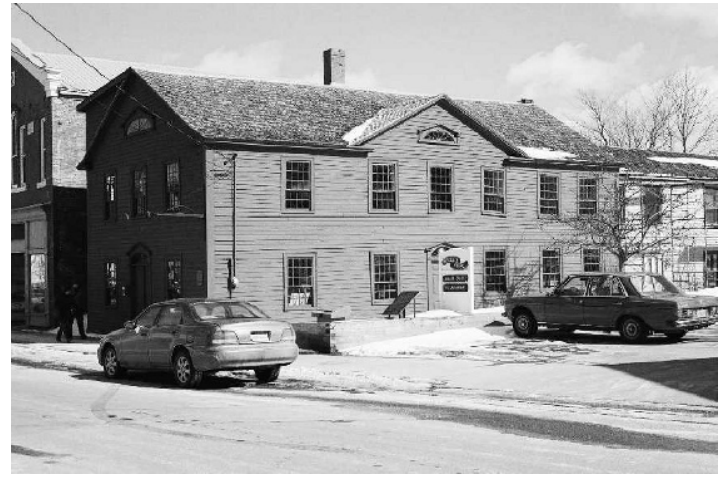

Figure 2. The Sinclair Inn in 2005. The inn has a very controversial date of construction, and is suspected to have been built by adding two separate buildings together to form one larger structure.

that some reports indicate was built in 1781 by Frederick Sinclair by joining two earlier built houses (Moody 1982). The front part of the inn was probably the house owned by Jean-Baptiste Soullard and his Acadian wife Françoise Comeau. He was a silversmith and gunsmith, but moved back to Nouvelle-France (now Québec) after the British took over Port Royal in late 1710. It is alleged to have been built on the current property, most likely in 1710 (Moody 1982). The back section of the inn may also be an older structure that was not originally built on the current property, but brought there later to increase the size of the Soullard House and combine the two structures to create the present day inn. Although it is not known for certain, the house could have been owned by William Skene, the English regimental surgeon, and was most likely built between 1707 and 1710 (Moody 1982). Moody (1982) also proposed that this structure could have been built as early as the 1690s, although history suggests that a fire destroyed the majority of the town in 1707 , leaving very few buildings standing (Dunn 2004).

The inn itself was thought to be built on the current site in 1781 by joining the Soullard twostory house already at the location, to the Skene one-story house that was moved during construction (Moody 1982). At this time, a second story was added to the Skene House and a new roof was constructed to cover both parts of the inn. However, according to the curator of the Musée
Acadien (B. LeBlanc, personal communication, 2007), the inn could have existed even earlier than 1781, as there are historical paintings, drawings, and maps (e.g. Hamilton 1753) that illustrate a two-story building somewhat similar to the inn already existing at the same approximate location. Although historical documents and architectural evidence strongly suggest that the Sinclair Inn could be one of the oldest known frame construction structures still standing in Canada, this assessment has no definitive proof.

The main objective of this study was therefore to date the various parts of the Sinclair Inn and settle the controversy, but to do so, another perhaps more difficult objective needed to be met: to develop and extend regional tree-ring chronologies that would overlap the suspected age of the Sinclair Inn. To complete this task, three separate buildings of known ages (the Karsdale and Middleton churches, and the Adams-Ritchie House in Annapolis Royal, Figure 1) were used as a surrogate to an old-growth forest in the region.

\section{METHODS}

\section{Obtaining Reference Chronologies}

To establish a reference chronology, we searched for local wooden structures with known historical dates of construction that would overlap the proposed time frame of the Sinclair Inn construction. After consulting with the Annapolis Heritage Society, three sites were selected to develop reliable local reference chronologies for crossdating. The first was the Christchurch Anglican Church located in Karsdale, Nova Scotia, about $7 \mathrm{~km}$ west of Annapolis Royal (Figure 1). It was well documented to have been constructed in 1791 (Duffus et al. 1982), although the wood was cut in the two years prior to construction. The second site was the Holy Trinity Anglican Church in Middleton, Nova Scotia, located about $42 \mathrm{~km}$ east of Annapolis Royal (Figure 1) and documented to have been built in 1790 (Duffus et al. 1982). The third site is the Adams-Ritchie House located in Annapolis Royal (Figure 1) near the Sinclair Inn. Originally a single-story house with wattle and daub construction, it is now a two- 
story structure used as a commercial space known as Leo's Café. The lower part of the structure was of interest because this part is assumed to have been built after the 1744-1746 attacks by the French and the Mi'kmaq when many buildings in Annapolis Royal were again destroyed (Dunn 2004).

At both churches, we had easy access to the attics where numerous beams and rafters were available for sampling. At the Adams-Ritchie House, we only had access to ceiling beams of the first floor, but they were in excellent condition and provided very good dating material. Additionally, most had bark remnants that ensured that we had access to cutting dates.

\section{Obtaining the Inn Samples}

We selected suitable material and strategic beams to ensure we covered all of the different parts of the building to be dated. Various structural beams and posts, including sills, from the first floor of the inn belonging to the original Soullard House and the Skene House were available for sampling. We only cored the timber that still had bark present. Wood material added later when the two buildings were joined was collected in the upper levels, mainly rafters and joists from the third floor. They are hereafter named the Sinclair additions.

\section{Processing}

At all sites, cores were extracted from the selected beams using a standard increment borer. Samples were placed into plastic straws and labeled following a log sheet describing each site. All samples were transported back to the Mount Allison Dendrochronology Laboratory. Samples were glued onto wooden mounting boards and then carefully sanded using progressively finer sandpaper. Ring-widths of the samples were measured to the nearest $0.001 \mathrm{~mm}$ using a Velmex stage system interfaced with Measure J2X software.

Before crossdating, wood from different beams was identified to species. This was deemed important to allow for crossdating with samples from the same species' reference chronology, which would therefore lead to more accurate results. Excess fragments of selected cores were set aside and representative samples were chosen based on visual characteristics such as wood color and features visible under a dissecting microscope (presence or absence of resin canals and similar early/late wood transition patterns). Observations of wood anatomical structures were then completed on a Scanning Electron Microscope (SEM) at magnifications between $70 \times$ and $5,000 \times$ and compared to a reference collection of wood species of the Maritimes. All other samples were identified with an optical microscope.

Three spruce species are found in Nova Scotia: red spruce (Picea rubens Sarg., the dominant spruce and most commonly used timber species), black spruce (P. mariana (Miller) BSP, the smallest of the three, confined to wetter areas and unfit for timber use), and white spruce ( $P$. glauca (Moench) Voss, the rarest of the three species). White spruce can be distinguished with the use of anatomical features, but red and black spruce cannot and are even known to produce hybrids. However, bark features, timber dimensions, and documentation of wood orders from local mills allow us to assume with high confidence that all spruce timber in this study is $P$. rubens.

Once all samples were identified, individual samples of the most abundant species (see results) were first visually crossdated and then the measurement data were statistically crossdated using COFECHA (Holmes 1983; Grissino-Mayer 2001). We then built average standardized ringwidth chronologies with each of the floating local chronologies using ARSTAN (Holmes et al. 1986) (single detrending using a negative exponential, cubic smoothing spline, or a linear regression detrending curve) and used the curves to later visually and statistically compare them with our reference data.

\section{RESULTS}

At the Soullard House seven cores were collected, while the Skene House provided eleven cores. Only four workable samples from the Sinclair additions were obtained. At the Karsdale 
Table 1. Wood identification results from the buildings used in this study.

\begin{tabular}{lcccc}
\hline \multicolumn{1}{c}{ Building } & $\begin{array}{c}\text { Spruce } \\
\text { (Picea cf. rubens) }\end{array}$ & $\begin{array}{c}\text { Fir } \\
\text { (Abies blasamea })\end{array}$ & $\begin{array}{c}\text { Eastern White Pine } \\
\text { (Pinus strobus) }\end{array}$ & $\begin{array}{c}\text { Eastern Hemlock } \\
(\text { Tsuga canadensis })\end{array}$ \\
\hline Christchurch, Karsdale & 11 & & \\
Holy Trinity Ch., Middleton & 13 & & 7 \\
Adams-Ritchie House & 6 & 4 & 2 \\
Soullard House & 3 & & \\
Skene House & 9 & 1 & & \\
Sinclair Inn additions & 3 & & & \\
\hline
\end{tabular}

church, the Middleton church, and the AdamsRitchie House, we were able to collect 11, 20, and 6 viable samples, respectively (Table 1). Most had bark, which ensured the establishment of cutting dates for each building.

\section{Wood Identification}

The wood identification process proved to be essential because most buildings had multiple species of wood present in their structures that were not readily distinguishable by the naked eye (Table 1). The most common species of timber used in construction at all buildings was red spruce (Picea rubens) and this allowed us to crossdate between all sites. All of the viable Karsdale ( $\mathrm{n}=$ 11) and Adams-Ritchie cores $(n=6)$, and the majority of samples from the Middleton church (13 of 20), Skene House (9 of 11), Soullard House ( 3 of 7 ), and the Sinclair additions (3 of 4) were identified as red spruce (Table 1). The remaining beams were identified as balsam fir (Abies balsamea (L.) Mill.), eastern white pine (Pinus strobus L.), and eastern hemlock (Tsuga canadensis (L.) Carrière) (Table 1). Only the red spruce samples were retained for crossdating in the subsequent analysis because of concern about sample depth and the lack of reference material to achieve reliable crossdating.

\section{Reference Chronologies}

Interseries crossdating for the Karsdale, Middleton, and Adams-Ritchie chronologies was conducted using COFECHA and tested visually. Nine of the 11 Karsdale samples were used while the two remaining cores could not be dated because of their very short series length (28 and
39 rings). The COFECHA analysis on the Karsdale church samples yielded an average interseries correlation of 0.51 (average age $=93$ years; std. dev. $=26$ years). For the Middleton tree-ring data, all spruce samples correlated significantly with each other $(\mathrm{n}=13$; average $\mathrm{r}=0.52 ; \mathrm{p}<$ 0.01 ) (average age $=100$ years; std. dev. 30 years). Of the six spruce cores from the Adams-Ritchie House, only one correlated poorly visually and statistically with the other five and we chose to reject it from the floating local chronology. The remaining five samples had an average series correlation coefficient of $0.47(\mathrm{p}<0.01)$ (average age $=99$ years, std. dev. $=39$ years $)$.

A red spruce chronology was obtained from southeastern New Brunswick that spanned far enough back in time (1735-2006) to crossdate with the outermost years of the two churches in Nova Scotia. It was made by combining one chronology from an old structure and one living tree chronology (Selig et al., 2008) (Figure 3A). The two churches were cross-referenced with the New Brunswick data using visual comparisons of standardized curves and statistical correlations using COFECHA. Results showed that: 1) the Karsdale church trees were cut in 1789 , consistent with the building of the church a few years later in 1791 (Duffus et al. 1982) (Figure 3B), and 2) the 1788 end date of the Middleton chronology is also consistent with the building of the church in 1790 (Duffus et al. 1982) (Figure 3C). As a result, two chronologies of 168 years (Karsdale, 1622-1789) and 153 years (Middleton, 1636-1788) were created.

The Adams-Ritchie chronology was then compared statistically and visually to the newly developed regional chronologies from the two churches. The end date is 1747 (Figure 3D) and 


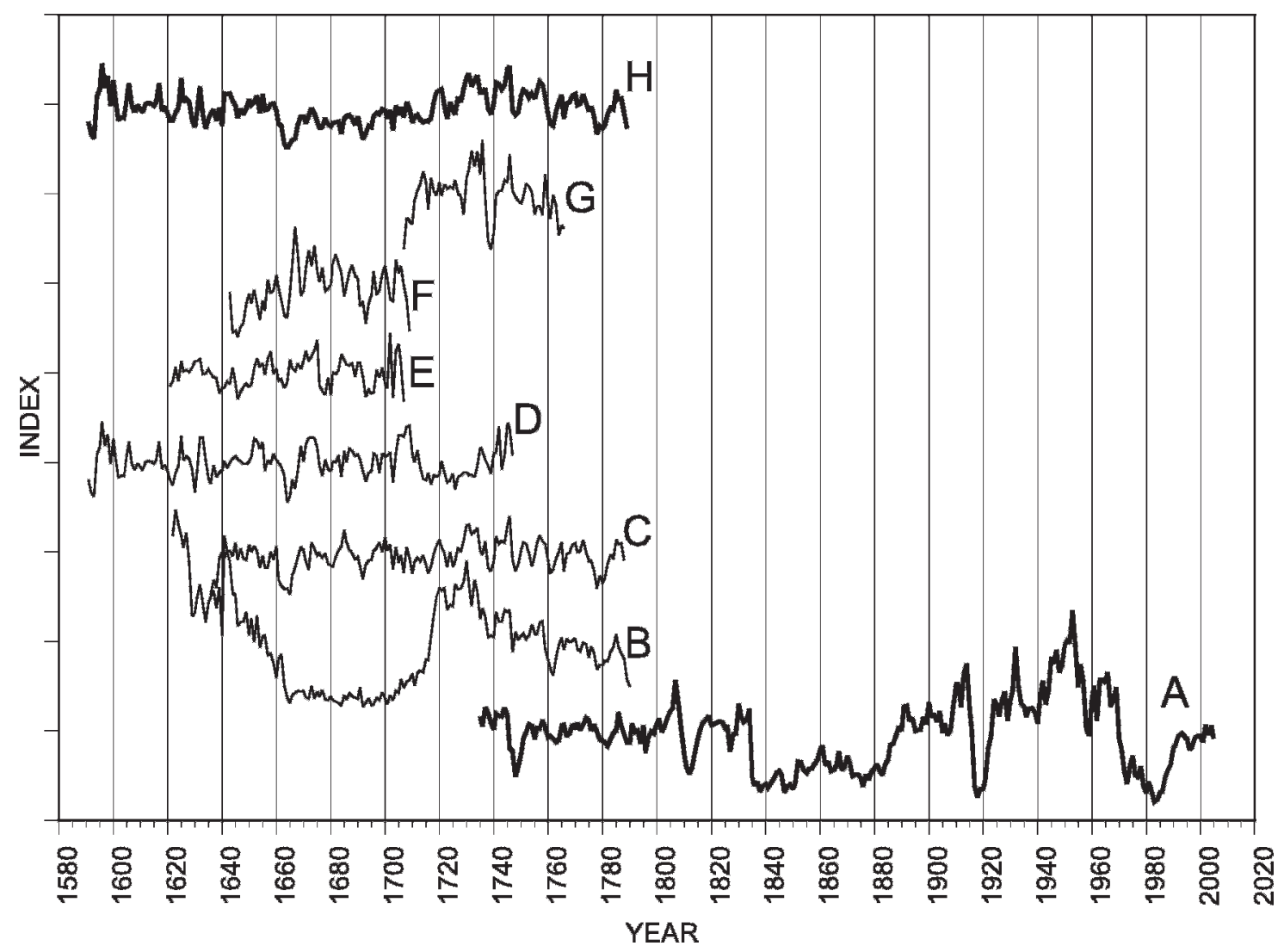

Figure 3. Standardized curves developed in this study. A - Southeastern New Brunswick regional chronology (bold bottom curve). B - Christchurch, Karsdale, Nova Scotia; cutting date: 1789. C - Holy Trinity Church, Middleton, Nova Scotia; cutting date: 1788. D - Adams-Ritchie House, Annapolis Royal, Nova Scotia; cutting date: 1747. E - Soullard House, Annapolis Royal, Nova Scotia; cutting date: 1709-1710. F - Skene House, Annapolis Royal, Nova Scotia; cutting date: 1708-1709. G - Sinclair Inn additions, Annapolis Royal, Nova Scotia; cutting date: 1768-1769. H - new southwestern Nova Scotia regional floating chronology (combination of B to G; bold top curve).

confirms the earlier assumptions that the AdamsRitchie House was built after the French/Mi'kmaq 1744-1746 attacks on Annapolis Royal (Dunn 2004). The Adams-Ritchie House spans 157 years (1591-1747), and it extended the overall regional chronology far enough back in time to test the crossdating from the different parts of the Sinclair Inn.

\section{Sinclair Inn - Soullard House (front of the inn)}

The three usable samples from the Soullard House were first standardized with ARSTAN before being used in a visual crossdating procedure against the new regional chronology. The procedure presented only one possible location of fit for the cores against the reference chronology. COFECHA showed a high degree of statistical correlation $(0.34,0.42$, and 0.66$)$ (average age $=$ 62 years, std. dev. $=26$ years) with the regional chronology and revealed a cutting date of 1710. A standardized average chronology was made with the three Soullard series and visually compared with the Adams-Ritchie chronology to further confirm the date (Figure 3E).

\section{Sinclair Inn - Skene House (lower back of the inn)}

Of the nine red spruce samples taken from the Skene House beams, two were badly damaged and not used in the crossdating procedure. Another one was rejected from further analysis because of 
Table 2. Cutting dates and minimal construction dates from this study.

\begin{tabular}{llrr}
\hline \multicolumn{1}{c}{ Building } & \multicolumn{1}{c}{ Estimated dates (from historical investigations) } & $\begin{array}{c}\text { Cutting dates } \\
\text { (This study) }\end{array}$ & $\begin{array}{c}\text { Minimal } \\
\text { construction date }\end{array}$ \\
\hline Christchurch, Karsdale & 1791 (Duffus et al. 1982) & 1789 & 1791 \\
Holy Trinity Ch., Middleton & 1790 (Duffus et al. 1982) & 1788 & 1797 \\
Adams-Ritchie House & After 1746 (Dunn 2004) & $1709-1710$ & $1747-1748$ \\
Soullard House & 1710 or after (Moody 1982) & $1708-09$ & $1710-1711$ \\
Skene House & 1690s, 1707-1710 or after (Moody 1982) & $1768-1769$ & $1769-1770$ \\
Sinclair Inn additions & Before 1751 (LeBlanc, personal communication) or & & \\
& $\quad$ around 1781 (Moody 1982) & & \\
\hline
\end{tabular}

low correlation with the remaining six series. However, those six series were successfully placed relatively to each other (mean $\mathrm{r}=0.49$ ) (average age $=42$ years, std. dev. $=13$ years). The standardized growth curves of the data show an established cutting date of trees in the series being 1709 (Figure 3F). Most series were short and only two cores contained the final annual growth ring because of the fragility of the outer wood of the beams.

\section{Sinclair Inn - Sinclair Additions (roof and upper level of the back of the inn)}

Three red spruce samples were taken from this section of the inn and were successfully placed relatively to each other. Interseries correlations produced by COFECHA were lower than the other parts of the house (mean $r=0.37$ ) (average age $=42$ years, std. dev. $=16$ years) but still significant (Figure 3G). The cutting date of the trees used for the construction of the roof that covers the Sinclair Inn was determined to be between 1768 and 1769 .

\section{DISCUSSION AND CONCLUSION}

\section{Resolution of Historical Inquiries}

The interpretation of dendroarchaeological dates can be highly problematic when the terminal ring of samples is absent (Nash 2002). Although it was an issue with some of the individual cores for our study, sufficient terminal dates were available to ensure precise dating of each of the buildings and the various parts of the Sinclair Inn (Table 2). From our experience in the region and from historical building practices that were recorded in great detail, it is generally known that the time lapse between cutting dates and the true beginning of the construction of a structure might be a season or a year in most cases, but it can be up to four years. As a rule, one year can realistically be added to the cutting date to determine the year that the structure was completed except when the final construction date is known as in the case of the Middleton and Karsdale churches. As a result, accurate construction dates were determined for all buildings tested (Table 2). Problems of age interpretation in the building origins that led to the controversies or uncertainties in the histories of the buildings in this study have been resolved by our dendrochronological analysis. The results substantiate the claims of some of the ages of the structures and eliminate other possibilities.

Although no surprises were found for the dates of construction from the analysis of the Karsdale and Middleton churches, the chronologies developed from these structures were the first step in the procedure to ultimately date the Sinclair Inn and develop a regional chronology for southwest Nova Scotia. As a result of locking in these dates, the church chronologies enabled us to crossdate the Adams-Ritchie House and add it to the overall growing regional chronology. The Adams-Ritchie chronology expanded the church chronologies by only four decades to roughly 200 years of length, but it more importantly strengthened the regional data sample depth, which ultimately became the main reason that we could date the Sinclair Inn.

Consequently, we were able to confirm that the Skene and the Soullard houses date to the early $18^{\text {th }}$ Century (1709 and 1710 , respectively) 
and were among some of the earliest buildings raised after the burning of the town in 1707 (Dunn 2004). The Soullard House then becomes a major find for the history of the region because few French pre-deportation (pre-1755) houses have been found in the Maritimes.

As for the Sinclair Inn itself, the beams used to join the two structures were supposed to help date the merging of the Skene and Soullard structures and the making of the inn, but only establish that the roof as it now stands was made in the late 1760s. It can still be speculated that the joining of the houses was made earlier, perhaps after the 1744-1746 attacks and before 1751, the latter being the earliest date from the paintings and drawings showing a two-story building where the inn currently stands. It is also not impossible that the actual roof was part of renovations made several years after. To disprove any further speculations, we would need to investigate timbers from the section added on top of the lower back part (the Skene one-story house) of the inn. That section was not accessible at the time of the sampling, but future access may be available sometime in the future during further renovations of the inn.

\section{Regional Tree-Ring Chronology Development}

Our second objective to develop a new regional chronology for southwest Nova Scotia was also successful, although the process was problematic and time-consuming. Using a step by step procedure of building one chronology onto another proved essential and demonstrates that it is possible to create long-term tree-ring chronologies in the Maritimes despite the highly unfavorable situation of having little to no old-growth forest. The existing new regional chronology (Figure $3 \mathrm{H}$ ) will now make it possible to crossdate other buildings that contain old ring sequences from the region.

The relatively high agreement between the southeastern New Brunswick curves and the local southwestern Nova Scotia curves created in this study should also be noted. After we combined the Karsdale, Middleton, and Adams-Ritchie structural chronologies to form a regional chronology
( $\mathrm{n}=26$, average $\mathrm{r}=0.49$ ) and compared it to the southeastern New Brunswick master, we found that both master chronologies follow each other fairly closely $(r=0.40)$, if only for a short period (55 years). This opens up some future interpretation for studies on past climate conditions from the two similar, but not identical locations. This highly valuable data would not only make it possible to attempt climate reconstruction, but could also help historians explain past events that affected the local populations, regional agricultural development, or even the role that climate may have played in the European colonization process as a whole. In conclusion, the use of old buildings in this little-studied region has a promising future. The development of valuable old tree-ring records in a region void of old-growth forests has many positive paleoclimatological and paleoenvironmental reconstruction possibilities, as well as being able to bring to light accurate dating information for historical research purposes.

\section{ACKNOWLEGMENTS}

We would like to thank the Annapolis Heritage Society for granting us access to the building, and the Biogeography class of winter 2005 for their sampling help. We would like to thank the Mount Allison Digital Microscopy Facility for their help with the SEM. We would also like to thank NSERC, Leadership Mount Allison, and the Marjorie Young Bell Faculty Funds for financial contributions to this project.

\section{REFERENCES CITED}

Baillie, M. G. L., 1982. Tree-Ring Dating and Archaeology. The University of Chicago Press, Chicago; 274 pp.

Dunn, B., 2004. A History of Port-Royall Annapolis Royal 16051800. Nimbus Publishing, Halifax; 286 pp.

Duffus, A., E. MacFarlane, E. Pacey, and G. Rogers, 1982. Thy Dwellings Fair: Churches of Nova Scotia 1750-1830. Lancelot Press, Hantsport, Nova Scotia; 189 pp.

Fergusson, C. B., 1967. Lumbering in Nova Scotia: 1632-1953. Adapted from an address by C.B. Fergusson, Provincial Archivist, November 1954. NovaScotia Department of Lands and Forests, Bulletin 26, 25 pp.

Hamilton, J., 1753. View of the Town \& fort of Annapolis Royal Nova Scotia taken on the Spot. Painting by Capt. J. Hamilton of His Majesty $40^{\text {th }}$ Regiment foot, $c a .1753$. 
Hawboldt, L. R., and M. Bulmer, 1958. The Forest Resources of Nova Scotia. Department of Lands and Forests, Halifax; 171 pp.

Holmes, R. L., 1983. Computer assisted quality control in treering dating and measurement. Tree-Ring Bulletin 43:69-78.

Holmes, R. L., R. K. Adams, and H. C. Fritts, 1986. Tree-ring chronologies of Western North America: California, Eastern Oregon, and Northern Great Basin, with procedures used in the chronology development work, including users manuals for computer programs COFECHA and ARSTAN. Chronology Series VI. Laboratory of Tree-Ring Research, University of Arizona, Tucson.

Grissino-Mayer, H. D., 2001. Evaluating crossdating accuracy: a manual and tutorial for the computer program COFECHA. Tree-Ring Research 57:205-221.

ITRDB, 2007. International Tree-Ring Data Bank (http://www. ncdc.noaa.gov/paleo/ treering.html).

Johnson, R. S., 1986. Forests of Nova Scotia. Four East Publications and Nova Scotia Department of Lands and Forests, Halifax; 407 pp.

Loo, J., and N. Ives, 2003. The Acadian forest: Historical condition and human impacts. The Forestry Chronicle 79: 462-474.

Moody, B. M., 1982. The Sinclair Inn, Annapolis Royal. Origins to 1781. Report for the Annapolis Heritage Society, $23 \mathrm{pp}$.
Nash, S. E., 2002. Archaeological tree-ring dating at the millenium. Journal of Archaeological Research 10:243-275.

Schweingruber, F. H., 1988. Tree rings - Basics and Applications of Dendrochronology. Kluwer Academic Publishers, Dordrecht; 276 pp.

Selig, N. E., C. P. Laroque, and S. Marsh, 2008. Dendroarchaeological investigations in the Maritimes: A case study of Dorchester House, New Brunswick. Material Culture Review 66:42-49.

Townsend, P., 2004. Nova Scotia Forest Inventory Based on Permanent Sample Plots between 1999 and 2003. Nova Scotia Natural Resources-Forestry Division, Report 2004-3, Halifax; $31 \mathrm{pp}$.

Wight, G. D., and H. D. Grissino-Mayer, 2004. Dendrochronological dating of an Antebellum Period house, Forsyth County, Georgia, U.S.A. Tree-Ring Research 60:91-99.

Wilson, S. J., and R. Colman, 2001. The Nova Scotia Genuine Progress Index Forests Accounts. Summaries of Volume 1 and Volume 2. GPI Atlantic: measuring sustainable development, National Roundtable on the Environment and the Economy, Government of Canada, Ottawa; $20 \mathrm{pp}$.

Received 3 July 2007; accepted 5 February 2008. 